\title{
Towards an archipelagraphic literary methodology: reading the archipelago in Julieta Campos' The Fear of Losing Eurydice
}

\author{
Dani Redd \\ University of East Anglia, UK \\ d.redd@uea.ac.uk
}

\begin{abstract}
Despite the recent archipelagraphic turn in island studies, there have been few literary studies of the archipelago. This paper has three aims. The first is to bring to light an archipelagraphic literary text that has not yet been explored in Island Studies Journal: Cuban writer Julieta Campos's The Fear of Losing Eurydice. The second is to develop 'archipelagraphy' (a term coined by DeLoughrey) into a methodology for reading literary texts, putting it into practice through an analysis of The Fear of Losing Eurydice. This archipelagraphic analysis reveals that Campos' text destabilizes the concept of the island as tabula rasa, an end-goal in a utopian quest. Instead utopia emerges as a call uttered by multiple voices across different times and spaces, resulting in the 'archipelago of desire' motif. This emancipatory cartography remaps western geographies of centre and periphery, instead stressing the connections between the Caribbean, Asia, Europe, and Africa. The paper's final aim is to provide a working definition of an archipelagraphic text.
\end{abstract}

Keywords: archipelagraphy, archipelagic relations, Julieta Campos, Poetics of Relation, The Fear of Losing Eurydice

https://doi.org/10.24043/isj.37

(C) 2017 — Institute of Island Studies, University of Prince Edward Island, Canada.

\section{Introduction}

The aims of this essay are threefold. First, I wish to bring to light a novel that has not yet been discussed in Island Studies Journal, but which plays a vital role in unsettling and interrogating representations of islands in western, continental literary narratives: Cuban author Julieta Campos' The Fear of Losing Eurydice (first published as El miedo de perder a Eurídice in 1979; Campos, 1979). Second, I wish to develop the concept of archipelagraphy, a term first coined by Elizabeth DeLoughrey, as a methodology for reading and analysing literary texts. Finally, I wish to conclude by providing a working definition of an archipelagraphic text and position The Fear of Losing Eurydice as a fundamental example of one.

In Island Studies Journal the significance of the archipelago has already been explored in diverse essays on tourism, political science, and even video games (Anckar, 2007; Baldachinno \& Ferreira, 2013; Nyman, 2013). Essays have also been published on the importance of the archipelagraphic perspective to island studies (Pugh, 2013; Stratford et al., 2011). However, there are few literary studies of archipelagos. There is a necessity to address this absence, for as Stratford (2013, p. 4) states, "thinking with the archipelago may reveal multiple emancipatory narratives that enunciate exceptions to colonizing grammars of empire that rendered islands remote, isolated and backwards." The Fear of Losing Eurydice is one example of such narratives. In this novel, Campos deconstructs the depiction of the island in colonial narratives as tabula rasa, easily encompassed and inscribed. She then draws upon the motif of the archipelago to create an emancipatory cartography, one which blurs the boundaries between Europe, Asia, Africa, and the Americas, between islands real and imagined. This essay explores the significance of that transformative movement, deepening understanding of what it means to think with the archipelago in a literary context. 
Julieta Campos is an experimental writer whose work blurs discursive boundaries. She has a doctorate in philosophy from the University of Havana and studied contemporary French literature at the Sorbonne. According to Cynthia Tompkins (2006, p. 19), "Campos's deep knowledge of the nouveau roman, the neobaroque, and surrealism, as well as the pleasure she derives from the Boom's stylistic and metafictional experimentation, allow her to pioneer a hybrid Latin American literary postmodernism." The nouveau roman is a style of writing that emerged in the 1950s and 1960s in France and is associated with writers such as Marguerite Duras, Nathalie Sarraute, and Alain-Robbe Grillet. It rejects linear plot and characterisation in favour of "precise physical descriptions, a heightened sense of ambiguity with regards to point of view, radical disjunctions of time and space, and self-reflexive commentary on the processes of literary composition" (Keep et al., 1993-2000), all of which are characteristics of The Fear of Losing Eurydice. Meanwhile, Tompkins (2006, p. 1) places Campos alongside Latin American female writers such as Clarice Lispector, Helena Parente Cunha, and Luisa Valenzuela, whom she believes "produce ludic, experimental, deconstructive, and self-reflexive texts [that] question the status quo from a woman centred position." Campos' engagement with these literary movements shows her interest in subverting and revising conventional narrative poetics. Her literary style therefore draws inspiration from both the Americas and from Europe- a transnationalism that is reflected in the cartographies of The Fear of Losing Eurydice. This essay uses an archipelagraphic analysis to trace the relations between and among islands in Campos' text, exploring the potential of its archipelagraphic structure to unsettle western stereotypes of islands.

English translations of sources have been used when available, including the primary source text. Those texts only available in Spanish have been quoted in the original and accompanied by my own translation.

\section{Archipelagraphy as a methodology for reading The Fear of Losing Eurydice}

No island is an isolated isle and [that] a system of archipelagraphy - that is, a historiography that considers chains of islands in fluctuating relationship to their surrounding seas, islands and continents - provides a more appropriate metaphor for reading island cultures (DeLoughrey, 2001, p. 23).

Islands are often perceived and analysed according to their boundedness — as outcroppings of land surrounded by sea-or in their peripheral relation to the continental mainland. Meanwhile, Caribbean and Pacific islands have traditionally been depicted in western cultural narratives according to several pervasive stereotypes: as exoticised utopias or remote sites for colonial exploration and conquest. The archipelago contains the potential to unsettle these stereotypes, for it emphasizes relationality; "the disjuncture, connection and entanglement between and among islands" (Stratford et al., 2011, p. 114). 'Archipelagraphy', a term coined by Elizabeth DeLoughrey (2001), is a name given to the collective call from writers and theorists of the Caribbean and Pacific for a remapping of such marginalizing narratives. Instead of a series of isolated isles, archipelagraphy evokes a "cartography of archipelagoes that maps the complex ebb and flow of immigration, arrival, and of island settlement" (DeLoughrey, 2001, p. 23). It draws inspiration from Édouard Glissant's (1997) Poetics of Relation and Kamau Brathwaite's (1999) 'tidalectics', amongst others.

Glissant's (1997, p. 11) Poetics of Relation offers a way of (re)conceptualizing the Caribbean archipelago which, as he informs us, is based upon Deleuze and Guattari's concept of the rhizome:

An enmeshed root system, a network spreading either in the ground or in the air, with no predatory rootstock taking over permanently. The notion of the rhizome maintains, therefore, the idea of rootedness but challenges that of a totalitarian root. Rhizomatic thought is the principle behind what I call the Poetics of Relation. 
The rhizomatic thought of Relation challenges the notion of a unity, instead evoking the concept of multiple, interconnected unities. 'Root' is not just a reference to the concept of belonging, of rootedness, but also to language, which is often discussed using a terminology of roots (i.e. Romance languages) and branches (Spanish, Portuguese, Italian). The vernacular of the Caribbean does not stem from one root, it is the product of multiple languages carried across the sea from Europe, Asia, and Africa; each Caribbean island has its own distinct phrases, speech-patterns, and vocal rhythms. This process of creolization, according to Glissant (1997, p. 34), "approximates the thought of Relation as nearly as possible" and can be viewed in an emancipatory light, for it creates "a new and original dimension allowing each person to be there and elsewhere, rooted and open." Therefore, Glissant moves away from creolization as a form of appropriation or mimicry, instead stressing its inventive, transformative dimension (as does Pugh, 2013).

The islands of the Caribbean are sites of Relation, spaces embodying multiple linguistic and colonial encounters. Glissant (1989, p. 139) states "each island embodies openness. The dialectic between inside and outside is reflected in the relationship of land and sea." This relationship reconceptualises the binary of land and sea established in western thought, where the sea is designated as aqua nullius, a space devoid of signifiers, which encircles and isolates the island. Instead, Glissant (1997, p. 6) perceives the islands of the Caribbean archipelago as being transformed by a network of ocean journeys: of "traditional races of yoles and gommiers," "glorious regattas," and the trauma of the Middle Passage, "a beginning whose time is marked by these balls and chains gone green." Glissant's Poetics of Relation therefore evokes not only the novelty of creation, but also emphasizes the trauma of history.

Glissant is one of numerous writers and theorists who stress the importance of the sea in the identity-formation of the Caribbean archipelago. In Roots and Routes DeLoughrey interprets Kamau Brathwaite's tidalectics as a concept which provides a cyclical alternative to western models of history and the linear crossings made by colonial settlers. Instead, DeLoughrey $(2007$, p. 2) states, "this 'tidal dialectic' resists the synthesizing telos of Hegel's dialectic by drawing from a cyclical model, invoking the continual movement and rhythm of the ocean." She uses a tidalectic model to highlight the complex and shifting relations between and among the islands in the Caribbean and Pacific archipelagos. Meanwhile, for Compton (2001, p. 17), "tidalectics describes a way of seeing history as a palimpsest, where generations overlap generations, and eras wash over eras like a tide on a stretch of beach." Compton also believes that black ontologies, specifically Caribbean poetry, dub, and hip-hop, are informed by tidalectic repetitions, his primary example being re-mixing. This suggests that one aspect of a tidalectic literary analysis could involve scanning a text for repeating rhythms or motifs.

Like Glissant and Brathwaite, Benítez-Rojo (1996, p. 11) also stresses the aquatic nature of Caribbean culture: "the natural and indispensable realm of marine currents, of waves, folds and double-folds, of fluidity and sinuosity." He uses chaos theory to suggest that the Caribbean is "a cultural meta-archipelago without centre and without limits, a chaos within which there is an island that proliferates endlessly, each copy a different one" (Benítez-Rojo, 1996, p. 9). The apparent contradiction in the last clause is deliberate. Not only does Benítez-Rojo (1996, p. 9) suggest the archipelago is the product of a series of repetitions with its roots in the "colonial machine" ("machine' is here used in the Deleuzian sense of a rhizomatic assemblage) which results "in the proliferation of the plantation machines" and a series of other repetitions across borders- "sugar islands, runaway slave settlements, air and naval bases" — but he also evokes difference, suggesting each island of the archipelago has its own distinct linguistic and cultural identity.

So far, I have discussed archipelagraphy as a historiography that affects a remapping of the Caribbean. How, then, does it manifest as a literary methodology? What is involved in tracing the archipelagraphic relations of a text? A point of departure can be found in 'Envisioning the Archipelago', where Stratford et al. (2011) begin to consider archipelagraphy as a methodology by positing it as a form of counter-mapping:

A re-presentation of identity, interaction, space and place that comes across in different combinations of affect, materiality, performance, things. Such counter-mapping requires a 
double-destabilization: dislocating and de-territorializing the objects of study - the fixity of island difference and particularity — and constituting in their place a site or viewing platform by which they are perceived and analysed afresh and anew (Stratford et al., 2011, p. 114).

Archipelagraphy is a form of counter-mapping that affects a "double-destabilization", for not only does it sweep aside western notions of the island but also provides a new perspective on the way in which islands are perceived: it both disassembles and reassembles. An archipelagraphic text also performs these movements. Consequently, a fundamental aspect of an archipelagraphic literary analysis is to explore how the text destabilizes existing island stereotypes and the new island cartographies it establishes in their place.

The theories detailed above help develop and inform an understanding of what constitutes an archipelagraphic literary analysis. For example, Glissant's Poetics of Relation highlights the necessity of exploring how islands in a text might be structurally or thematically connected to each other. Meanwhile, Compton's reading of tidalectics-as-palimpsest suggests textual islands are multi-layered sites constructed from a multiplicity of historical and cultural perspectives, which need to be disentangled. The tidalectics of a text could pertain to manifestations of fluidity: to repeating poetic rhythms, recurring motifs, or a non-linear structure - all qualities The Fear of Losing Eurydice exhibits. Ultimately, however, the most fundamental aspect of an archipelagraphic literary analysis is to explore the subversive cartographies of a text: how does it challenge existing island stereotypes? What does it provide in their place?

Archipelagraphy as a methodology for reading literary texts is best understood when put into practice. Lisa Fletcher's analysis of Amitav Ghosh's (2006) The Hungry Tide, a novel set in the Sundarbans in the Bay of Bengal, provides one such example. Fletcher $(2011$, p. 9) states that in The Hungry Tide:

Ghosh uses the tide as a structuring device- the book is in two parts, one titled 'The Ebb: Bhata' and the other 'The Flood: Jowar' - and as the key metaphor in his deconstruction of the binaries which manage official histories of places such as the Sundarbans. For instance, by interspersing the contemporary narrative with extracts from Nirmal's diaries, he shows the past and present of the Sundarbans to be in fluid relationship of ebb and flow, in which no vision of the islands is fixed or invulnerable.

Here Fletcher explains how the structure of the book, a narrative "flow" between past and present that echoes the tides in this estuarine landscape, is used to deconstruct the dominant historical perspective of the Sundarbans. Fletcher (2011, p. 13) shows that within The Hungry Tide the Sundarbans are subjected to multiple mappings - a GPS map, the translation of a notebook, indigenous knowledge- and states that these "collectively evoke a conceptual Möbius strip on which the Sundarbans archipelago can only be comprehended in relation to factual and imaginary narratives." The archipelago emerges as an entanglement of real and imagined geographies. Its 'Poetics of Relation' are the points of congruence and tension between disciplines such as marine biology, translation, and ecocriticism, all of which inform Ghosh's narrative. To Fletcher (2011, p. 14), the novel "illustrates the degree to which no single disciplinary framework is up to the task of a comprehensive study of a particular island or archipelago." But might it not also highlight the subversive potential of the archipelago itself to destabilize linear narratives, to blur boundaries both between disciplines and geographies real and imagined? This is a question that my archipelagraphic anlaysis of Julieta Campos' The Fear of Losing Eurydice contributes understanding to.

I shall begin by focussing on The Fear of Losing Eurydice's "double-destabilization" (Stratford et al., 2011, p. 114); its deconstruction of island stereotypes and the creation of new insular cartographies. In the case of The Fear of Losing Eurydice, this refers to the western quest for utopia, a quest that is complicated and deferred within the text. Meanwhile, numerous islands repeat and proliferate through the text, together constituting a transnational meta-archipelago, "the archipelago of desire" (Campos, 1993, p. 102), which destabilizes the concept of the island as tabula rasa. 


\section{Undone by desire: destabilizing utopian cartographies}

America was always the goal, the Mecca of all nostalgias for remote places, of all dreams of islands. (Campos, 1993, p. 86)

The Fear of Losing Eurydice is at once a critique of and a glorification in utopian narratives. The type of utopian narrative it critiques is one of conquest and inscription, exemplified in the geographical movement from the West towards the Americas. Campos believes the utopian gaze has also been internalised by Cubans themselves. In an interview, she states that since the $19^{\text {th }}$ century many Cubans entertained "the fantasy of being the Island of Utopia, that privileged space for a transcendent vision. There, they would construct a democratic republic that would be an example for the rest of Latin America" (Torres Fiero, 2006). To Campos, Fidel Castro was one such Cuban; his visions of utopia led to "a perilous adventure that would end in a great wreck" (Torres Fiero, 2006). In providing this example, she indicates the potential danger of imposing utopian narratives onto a geographical space.

Campos' view of utopia is further developed through The Fear of Losing Eurydice's treatment of Jules Verne's Robinsonade, Deux Années des Vacances, one of the novel's many intertexts-I use the latter term according to Gérard Genette's (1997, p. 2) definition as "the actual presence of one text within another." Campos' narrator describes how in Verne's novel the schoolboys "will immediately trace out a map, imposing British names on the features of the island [...] order is re-established. Life will be governed by norms. Authority will be just and it will be engendered by consensus and reflection" (Campos, 1993, p. 13). Here the island is positioned as a tabula rasa, a desert island that is inscribed with "British names." The process of encompassment is legitimised by the words "order" and "authority" which designates the quest for the island as a rational, necessary one. Yet according to the narrator in The Fear of Losing Eurydice, these schoolboys are "simply dreaming, urged on by an unquenchable confidence in the resources of human reason to be able to construct paradise" (Campos, 1993, p. 13). This shows that for Campos, utopian discourse is not based upon logic and reason but on dreaming and desire. The Fear of Losing Eurydice represents an entanglement of rationalization and desire, evoking utopia not as a linear quest with a goal but as a transnational Poetics of Relation in which the island proliferates and repeats, evading capture and definition.

The Fear of Losing Eurydice also suggests that the desire for utopia is not Eurocentric but universal: "Who has never dreamed of a deserted island? We are all shipwreck survivors dreaming of islands," the narrator asks (Campos, 1993, p. 33). Indeed, as Maria Ramos de Hoyos (2016, p. 158) points out, Campos "parece caer también bajo el influjo de la misma seducción"/"also seems to fall under the same seduction." In 'Fragmentos de un diario al margen de un libro', a diary that Campos (1988) wrote alongside The Fear of Losing Eurydice, she lovingly describes journeys she has undertaken to islands in the Mediterranean and the Americas.

Within The Fear of Losing Eurydice, Campos draws upon this universal desire for the island to create a utopian narrative comprised of multiple textual sources. Indeed, The Fear of Losing Eurydice has a tripartite structure, which Tompkins initially likens to a Möbius strip (the same metaphor Fletcher uses to describe The Hungry Tide). It narrates the story of an "ideal couple, an archetypal couple" (Campos, 1993, p. 3) whose passionate encounters and separations are laid out in narrow columns of text. The wide margins that surround the story of the couple's encounters are populated by quotations drawn from literary sources, which range from Hesiod's Theogony to the poetry of Pablo Neruda. According to Tompkins (2006, p. 29), these quotations "iconically represent their content, since they tend to be very short texts referring to 'real' or fictitious islands." The main body of the text follows Monsieur N., a French teacher living on an unnamed Caribbean island, who becomes obsessed with collecting as many references to islands as possible in a travel diary - a literary search to discover and depict utopia. This narrative of multiplicity destabilizes the monologic, possessive gaze that seeks to conquer and possess islands.

We first encounter Monsieur N. in the Palace of Minos, a café on an unnamed Caribbean island, reading Jules Verne's Deux Années des Vacances. He pauses often to observe the couple at 
the adjacent table. Soon, he has distractedly drawn the outline of a napkin on a white napkin. This is an important hermeneutic gesture that the novel frequently returns to. He also begins to collect references to islands in a travel diary, his 'islandiary' (Campos, 1993, p.41). Both gestures initially emerge as a way of ordering and encompassing the island. Looking down upon his drawing of the island from a panoptic position, N. encodes it with his romantic fantasies; he "fondles the little island he had sketched on the napkin as he would be delighted to do with the girl at the table facing him" (Campos, 1993, p. 95). The island here signifies a substitute female body, a permissive space that enables him to enact his passionate fantasies. Meanwhile, the 'islandiary' has undeniable connotations with colonialism. Ironically, this is a link that is partially obfuscated in the translation of The Fear of Losing Eurydice, for Campos' (1979, p.79) original name for Monsieur N.'s travel diary was 'islario', a reference to the compendiums compiled in the Age of Discovery "of all the islands that are known and have been discovered to date," described "using painted figures and in writing" (Portuondo, 2009, p. 73). To Ann-Marie Fallon (2006, p. 143), Monsieur N.'s islario represents the "hegemonic vision" of colonialism; a linear taxonomic movement within the text that is ultimately frustrated by a poetic that emerges from its margins; "a surreal, alternative aesthetic practice which suspends the colonizing French and English languages [...] displacing his colonial claims to a New World." However, I believe that the islario reflects a reconfiguration rather than a failure of the utopian quest, highlighting it as a chaotic series of movements and repetitions instead of one linear thrust towards a goal.

Although the islario is a signifier of colonialism, it is also a representation of Campos' own writing practice. This is established through a reading of 'Fragmentos de un diario', in which Campos discusses the compositional process for The Fear of Losing Eurydice. Here she compares Monsieur N. to Zeus, "que introduce orden y cultura en un universo caótico"/ "who introduces order and culture into a chaotic universe" (Campos, 1988, p. 67). The imposition of order onto chaos is, she believes, the function of all writing, including her own. Indeed, she refers to writing The Fear of Losing Eurydice as an attempt to structure "esa profusión de fragmentos incoherentes que me asaltan" " "that profusion of incoherent fragments which assail me" (Campos, 1988, p. 58). These fragments refer to representations of islands she has encountered in music, myth, and literature, as well as on her own travels. Meanwhile, in the islario, Monsieur N. also details a profusion of island references:

Island: the place of utopia; a safe place on the world's fringe. Island: time without limits [...] Island: a place everywhere open and everywhere closed off. Island: petit coin ou les enfants vont jouer. Island: phalanstery. Island: every labyrinth is one, but not all islands enclose a labyrinth (Campos, 1993, p. 20).

This entry lists some of the symbolic significations associated with the word 'island'. The first two representations emerge from a western continental perspective, which has historically designated the island as an atemporal utopia located 'on the world's fringe'. The phalanstery is a reference to the enclosed utopian communities dreamed up by the Frenchman Charles Fourier. However, the concept of the island as a place "everywhere open and everywhere closed off" can be situated within a Caribbean context, an earlier echo of Glissant's (1989, p. 39) assertion that "the island embodies openness." Meanwhile, Benítez-Rojo (1996, p. 123) also refers to the Caribbean as a "vast hermetic labyrinth," a reference to its composition from various 'codes': languages, myths, and cultural rites from Europe, the Americas, Africa, and Asia (a thought I will return to). The islario therefore details representations of islands emerging from multiple cultural contexts.

For this reason, the island soon emerges as a signifier of multiplicity within the text. This is reflected in the island drawn on the white napkin. Initially a signifier for N.'s romantic urges, it soon begins to proliferate images and associations:

The maps surging out of the imaginary drawing of one association that leads to another, and so on in succession, are unsuspected; this map, which begins to constitute itself 
around a castle surrounded by a moat and the enclosed park of a Romantic cloister, shifts without transition into the map of the island of Crete, into the outline of a Venice still medieval, sanguineous and warm (Campos, 1993, p. 42).

The islands mentioned in this quotation, Crete and Venice, are both European. The reality of the Caribbean island on which N. lives has proved incompatible with his fantasies- "Monsieur $\mathrm{N}$. detests the tropics and would give anything to manage a transfer to a more sheltered spot with a kindlier climate" (Campos, 1993, p. 43) - and consequently his imaginary is saturated with longing for the islands he has left behind, islands not just distant in space but distant in time, for the Romantic and the medieval periods are alluded to. The quotation also the reflects the concept of the island as a space "everywhere open and everywhere closed off" mentioned in the previous paragraph. Whilst the words 'surrounded', 'enclosed', and 'outline' are demarcations of boundedness, phrases such as 'surging out' and 'shifts without transition' are representative of the fluidity with which the figure of the island unlocks phrases and associations. The flowing syntax of the sentence compounds this impression, ultimately destabilizing notions of boundedness.

The island is therefore the product of movement. Within the text it is often associated with the word 'surged', a word that signifies desire within the text. In fact, Campos makes an explicit connection between the island and desire:

In the beginning was desire. Desire begot the Word, which begot the couple, which begot the Island. The Island was paradise [...] it surged up out of chaos like a miracle, as language emerges from silence (Campos, 1993, p. 1).

These sentences parallel those of Genesis in the Old Testament, in which God invented the world by naming it and in doing so called it into being. Yet Campos states that it is desire which produces this urge for naming. Desire is the fundamental catalyst behind language, the couple, and the island. The island is a dynamic space that surges into being out of chaos, its journey a mimesis of literary creation, the emergence of language from the silence of the void.

However, these surges of desire are ultimately unstable. As Monsieur N. writes in his islario:

The Island, like the couple, is a transitory reality. The island ends by disappearing when one day the walls of water that have served as their protection topple over on them. The couple disappears when one of them begins to dream of another island (Campos, 1993, p. 76).

In associating the island with a romantic discourse Campos designates islands as 'transitory' spaces. Yet for every island which disappears, another is created. The narrator observes "the options in a love story are infinite; one can always start from zero and begin again" (Campos, 1993, p. 40). Since the island and the couple are interchangeable referents within the novel, the island too becomes a space of endless beginnings and infinite proliferation.

The island, viewed from this perspective, is no longer a tabula rasa. Instead, it can be perceived as a multi-layered site comprised of various textual references. This is a perspective that is recorded in the islario: "one must read Verne like a palimpsest: behind the discipline of Progress there is another, or perhaps several, invisible readings" (Campos, 1993, p. 74). A palimpsest refers to a piece of parchment which has been scraped clean and reused multiple times-traces of earlier writing still remain, which later writing is superimposed upon. Within The Fear of Losing Eurydice the text is synonymous with the island: "every text is an island" (Campos, 1993, p. 102). The island is therefore a palimpsest inhabited by multiple texts. Paul Rodaway (1994, p. 155) stresses this intertextual dimension to geographical space: "the text no longer comes before the virgin land and uncharted seas: the text comes before a text, which in turn comes before another text, and so on in an endless chain." This endless (inter)textuality is reflected in The Fear of Losing Eurydice, for the desire for utopia is not just articulated by Monsieur N. but by the quotations 
from other sources inhabiting the margins of the text. It becomes a call uttered by multiple voices across different time periods and geographical spaces.

The multiplicity in the text serves a function. According to Reina Barreto (2004-5, p. 43), "Monsieur N. finds his search for paradise deferred as it spins out of his control": he is unable to encompass the island in his islario as each island reference leads him to another. Indeed, N. soon realises the impossibility of his task: "There are 500,000 islands, not recorded on the world maps of course, but islands whose existence is attested to by the letters of navigators [...] I have proposed an unrealizable goal' (Campos, 1993, p. 101). On the last page of his notebook Monsieur N. writes "THE FEAR OF LOSING EURYDICE." Rather than coming to an end, his project is deferred, for it becomes imbricated in endless meta-textual cycles of repetition. Ultimately, Monsieur N. does not succeed in reaching utopia.

However, this deferral in regard to an ultimate meaning does not necessarily constitute a 'failure'. An alternative interpretation can be found by returning to the concept of Verne as palimpsest; in decoding the 'invisible reading' behind the narrative of progress that The Fear of Losing Eurydice later provides:

All of Verne is the story of a story of love postponed to infinity, never told, as if that prolonging of expectation, that deferment of the tension of desire over an infinite span would generate the most incisive of all enjoyments...the desire that was spent in search, in the journey to the island (Campos, 1993, p. 87).

Campos's reading of Verne shows that the pleasure of the utopian narrative is to be found in the journey towards the island, rather than in reaching it. The utopian narrative has therefore been remapped; it is no longer one of possession, but one of deferral. The pleasure of deferral replaces the act of inscription. To Campos, inscription has had damaging consequences for her birthplace, Cuba. For her, deferral is a politically motivated textual strategy which allows for the creation, not destruction, of island spaces.

\section{The archipelago of desire: a transnational cartography}

Island: the sum of all improbabilities; intoxicating improbability of fiction. Island: image of desire. Archipelago: proliferation of desire. All the islands formulated by human beings and all islands appearing on the maps comprise a single imaginary archipelago - the archipelago of desire. It is always in the process of infinite expansion (Campos, 1993, p. 102).

Within The Fear of Losing Eurydice, the island's proliferation leads inevitably to the introduction of an archipelagraphic motif, 'the archipelago of desire'. This motif suggests that all islands real and imagined are constructions of desire, and can therefore be connected into a 'single imaginary archipelago'. However, the 'archipelago of desire' is more complex than it initially appears. For a start, it is a self-referential metaphor, an allusion to The Fear of Losing Eurydice itself, a novel which thematically connects islands real and imagined to each other through the unstable surges of desire. Therefore, an analysis of the archipelagraphic relations between and among the text's islands leads to a deeper understanding of the 'archipelago of desire' motif.

The structure of The Fear of Losing Eurydice contributes understanding to the archipelagraphic relations of desire within the text. As Campos (1988, p. 67) informs us, "La estructura del libro es su propia metáfora"/"the structure of the book is its own metaphor." In the previous section I mentioned The Fear of Losing Eurydice has a tripartite structure, akin to a Möbius strip. However, this structure soon breaks down; according to Tompkins (2006, p. 29), it is subject to 'thematic contamination'. This occurs for several reasons. The first is that that Monsieur N.'s search for utopia and the lovers' search for paradise become conflated, for the rational discourse he initially embodies is exposed as being synonymous with the lovers' amorous discourse. The second is that 
the motifs and descriptions of islands in the quotations begin to repeat within the main body of the text, which also begins to generate textual references. My intention, in providing these examples, is to show that the discrete paragraphs in The Fear of Losing Eurydice are, in their own way, porous, open to a flow of metaphors and associations. According to Feracho (2005), Eurydice fits Umberto Eco's (1990, pp. 37-38) definition of an 'open work':

There exist works which, although organically completed, are 'open' to a continuous generation of internal relations which the addressee must uncover and select in his act of perceiving the totality of incoming stimuli.

An open work necessitates the reader as an active presence, uncovering and selecting references from a "continuous generation of internal relations." Despite their bounded appearance, the paragraphs within The Fear of Losing Eurydice are 'open' in their relation to one another; the "internal relations" Eco refers to can here be defined as the island metaphors that proliferate and move through the text. It is only by tracing individual connections that a totality can be perceived - in this case, the totality is the archipelago of desire and all it represents.

How, then, are the islands within the text connected to one another? Fallon (2011, p. 144) suggests they "are connected only by free association. Free association as an ordering principle creates a freedom of movement between geographic and textual spaces." The Fear of Losing Eurydice does indeed exhibit free associative movements, especially within the couple's perspective, which links islands to other geographical referents that then blend seamlessly into references of myths, music, carnivals, and oceanic descriptions, "the iridescent and tremulous luminosity of a seashell" (Campos, 1993, p. 64). Campos (1988, p. 67) herself likens this fluid aspect of her writing to "una música iridescente, acuática, que desvanece los límites" / "an iridescent, aquatic music which dissolves limits." This description evokes comparisons with l'écriture feminine, a style of feminine writing first described by the French theorist Hélène Cixous (1976, p. 876) in Laugh of the Medusa, who uses oceanic metaphors - "luminous torrents," "these waves, these floods, these outbursts" to evoke an elemental fluidity which can sweep away or subvert male 'marked writing', which is a symbolic system constituted through phallocentric reason, where each word is assigned a definite meaning (Cixous, 1976, p. 879). Therefore, linking Campos' writing to l'écriture feminine suggests her intent to destabilize established symbolic referents and value systems. In summary, the lyrical free association has a subversive purpose within the text: to collapse geography, connecting the Americas to Europe, and real places to imagined ones.

Indeed, to Barreto (2004-5, p. 43), the "images of Venice and Tenochtitlan and the Mediterranean and the Caribbean seas with their numerous islands merge into one." Many island metaphors within the text reflect this locational confusion:

Anyone could place it on the map, at the intersection

between the Atlantic and the Caribbean, an

island with gentle English meadows and

bridges and the sort of canals which some

voyagers, taken by surprise, associate with

Venice. An island of the Lesser Antilles,

extravagant with green and red birds, giant

ferns, palm trees (Campos, 1993, p. 75).

In this quotation, the island represents three cultural contexts simultaneously. Campos' depiction of the island here mirrors that of the symbolic formation of the Caribbean. According to DeLoughrey, Columbus gave two names to the archipelago. The first of these, the Antilles, comes from the eighth century legend of a Christian utopia, Antillia, which was reputed to lie in the Atlantic. This is a legend Campos refers to within The Fear of Losing Eurydice: "Antilia, 
invented in 1367 so that Christopher Columbus would dream of it" (Campos, 1993, p. 103). The other name, the West Indies, emerges because Columbus had been heavily influenced by Marco Polo's description of Asia, specifically the mythical island of Cipango, which he believed he was voyaging towards as he journeyed in the direction of the Americas. Upon arrival, "he thought he had reached parts of Asia previously unknown to Europeans and certainly unknown to Marco Polo [...] the farthest westward extension of Asia" (Philips, 1992, p. 150). These two examples show that the Caribbean is constituted from a series of "discursively repeating islands" and "a collapse of time-space," as well as being symbolically linked to both Europe and Asia (DeLoughrey, 2007, pp. 10-11). The Fear of Losing Eurydice reflects these symbolic geographies; it collapses time-space and many of the island metaphors it uses repeat through the text.

The Palace of Minos is one such recurring motif. To Ramos de Hoyos (2016, p. 141), it "conlleva una yuxtaposición de referentes geográficos, históricos y culturales claramente orientados a nivel simbólico e ideólogico"/"implies a juxtaposition of geographic, historic and cultural referents clearly oriented at an ideological and symbolic level." On the one hand, it refers to the Minoan civilization, and has symbolic connotations with the labyrinth-a symbol that figures prominently in Campos' oeuvre-and has mythic connotations with the story of the minotaur, of Theseus and Ariadne. Yet it is also the name given to the café on an unnamed Caribbean island where Monsieur N. spends most of his time. To rebuild a European monument in the Caribbean symbolizes "el conjunto de mitos y esperenzas que los europeos proyectaron hacia el Nuevo Mundo" "the set of myths and hopes that the Europeans projected towards the New World" (Ramos de Hoyos, 2016, p. 141). Therefore, the Palace of Minos, as it repeats throughout the text, not only collapses time-space but highlights the mythical and symbolic entanglements that occur through these discursive repetitions.

In this manner, The Fear of Losing Eurydice exemplifies the mythopoetical dimension of the Caribbean that is also found in both the theories of Glissant and Benitez-Rojo. The latter describes the Caribbean archipelago as:

A network of subcodes holding together cosmogonies, mythic bestiaries, remote pharmacopoeias, oracles... one of these subcodes may lead us into the labyrinth of Minos, another to the tower of Babel, another to the Arawak version of the Flood, another to the secrets of Eleusis, another to the garden of the unicorn, others to the sacred books of India and China and to the divining cauris of West Africa. (Benítez-Rojo, 1997, p. 17)

Not only does Benitez-Rojo (1996, p. 2) stress the transnational dimension of the Caribbean archipelago-for it (re)draws connections between the Americas, Africa, Asia, and Europe-but it also designates it as a symbol comprised of multiple textual codes. He highlights the necessity not only for a remapping but also a re-reading of the Caribbean, "the kind of reading in which every text begins to reveal its own textuality." The Fear of Losing Eurydice has some similarities with Benitez-Rojo's depiction of the Caribbean. Some of the symbolic referents described above are listed within its pages: "Island: the garden of the tapestry of the Virgin and the Unicorn" (Campos, 1993, p. 41); "minotaurs in aquatic labyrinths" (Campos, 1993, p. 15). Most importantly, however, the islands within the text are also comprised of a network of different texts.

The islands in The Fear of Losing Eurydice are not only connected by desire, but through an intertextual relationship, defined by Genette $(1997$, p. 2) as a "relationship of copresence between two texts or among several texts." Genette (1997, p. 399) believes it is reductive to consider a text in isolation; instead one must engage in a "relational reading," tracing the various literary presences that inhabit each text. The Fear of Losing Eurydice has multiple intertexts- the quotations in the margins, all from different cultural sources, influence the content of the main body of the text. According to Tompkins (1996, p. 176), the relationship between the quotations and the main text reflect the fact that The Fear of Losing Eurydice "stages intertextuality as différance." Differance is a term coined by Derrida (1982, p. 10), referring to "the movement according to 
which language, or any code, or any system of referral in general, is constituted 'historically' as a weave of differences." Within this movement, any final meaning is deferred. To Worton and Still (1990, p. 11), the use of quotations within a text links intertextuality to différance: "inevitably a fragment and displacement, every quotation distorts and redefines the "primary' utterance by locating it within another linguistic and cultural context," leading to "an awareness of infinite deferral and dissemination of meaning." The " "primary' utterance" within The Fear of Losing Eurydice is the island. Therefore, each quotation redefines and displaces the concept of the island by relocating it within a different context. This, then, leads to 'infinite deferral'. In other words, the structure of The Fear of Losing Eurydice reflects its thematic content, that of Monseiur N's inability to reach the island.

Exploring the intertextual relations in The Fear of Losing Eurydice is vital to an understanding of the text's archipelagraphic geographies:

The wind shook the crowns of the mango trees, made their oilskins rattle, and whistled through the crests of the palm trees with some ferocity. The cypresses and acanthuses sprang up in unison and the islet turned into an islet in the Aegean Sea, although the Aegean Islands are austere and stripped down, almost inhospitable. From a distance it was like a ship at anchor, or a gigantic fish, half above water and half below.

\author{
...there where the \\ Aegean sighs and \\ moans lies a dainty, \\ mild little island... \\ - Petrarch \\ ...what looks to you \\ like an island is not \\ what it seems but a \\ great fish that has \\ spread itself out to sleep \\ in the middle of the sea... \\ -A Thousand and One Nights
}

(Campos, 1993, p. 5)

The quotations from Petrarch and A Thousand and One Nights are placed in the margins of The Fear of Losing Eurydice and inform the content of the lovers' narrative. The Petrarch quotation depicts the island in the Aegean as dainty and mild, while the main body of Campos' text describes an island that contrasts starkly with this: a tropical island beset with winds of 'some ferocity'. However, the tropical island soon metamorphosizes into an Aegean islet, a connection which evokes the mythopoetical relationship between the Caribbean and the Aegean civilizations of Crete and Greece. Yet Campos' description of the Aegean Islands as "austere and stripped down, almost inhospitable," contradicts Petrarch's view of them as 'dainty'. Instead it more closely mirrors their designation by travellers such as Strabo and Juvenal as scopuli, or rocks in the ocean, which is, according to Constantakopoulou (2007, p. 23), a misleading depiction emanating from the Roman Empire that established the "topos of the 'weak' islander: poverty, isolation, political weakness"indeed, the once powerful Aegean islands were eventually annexed by the Roman Republic.

Campos is therefore indicating a relationship where the Aegean islands are marginalized by a source of continental power. Her description of the metamorphosing island then draws inspiration from the $A$ Thousand and One Nights quotation - the metaphor of the island as a "great fish" re-emerges as "a gigantic fish" within the main body of the text-indicating that Campos is drawing upon a Middle Eastern imaginary to call the reality of the island into question. In suggesting the island is not all that it seems, the power relationship established in the previous sentence - that of the island as subordinate to the continent - is subverted. Furthermore, the act of looking at the quotations in the margins to understand what is written in the main body of the text replicates this subversion. Meaning is decentred, for an archipelagraphic understanding 
of the novel can only be achieved by making connections between the main body of the text and the islands in the margins.

In summary, the intertextual relations in the text perform two functions. First, they complicate continental geographies in which the island emerges as peripheral to the mainland. This is something Ramos de Hoyos (2016, p. 140) also alludes to when she informs us that "más que una jerarquía o una derivación, se instaura un paralelismo, en que coexisten en un mismo plano diferentes elementos heterogéneos"/ "rather than a hierarchy or derivation, a parallelism is established, in which different heterogeneous elements coexist in the same plane." Second, an intertextual reading highlights the island's repetitions and transformations across geographical, historical, and cultural boundaries. The intertextual archipelago that emerges in a reading of The Fear of Losing Eurydice is synonymous with the archipelago of desire motif, in which all islands, real and imagined, are connected into "a single imaginary archipelago" (Campos, 1993, p. 102). According to the conclusions drawn above, the archipelago of desire emerges as a way of establishing an 'equal plane' between and among islands, rather than being a geocentric model in which the European continent emerges as the centre of power.

The archipelago of desire is a symbol of both repetition and différance, meaning it corresponds to Benítez-Rojo's (1996, p. 9) depiction of the Caribbean as "a chaos within which there is an island that proliferates endlessly, each copy a different one." Benítez-Rojo (1996, p. 111) describes how:

Within this series that original, that island at the center, is as impossible to reach as the hypothetical Antillas that reappeared time and time again, always fleetingly, in the cosmographers' charts. This is again because the Caribbean is not a common archipelago, but a meta-archipelago... and as a meta-archipelago it has the virtue of having neither a boundary or a center.

Just like Benítez-Rojo's meta-archipelago, the archipelago of desire has "neither a boundary or a center," meaning that the "original" island can never be reached. The archipelago of desire therefore emerges as a decolonizing gesture because it remaps western cartographies, abolishing notions of centre and periphery and instead stressing the palimpsestous connectivity between the Caribbean, Asia, Europe, and Africa. Within the archipelago each island proliferates endlessly, its meaning constantly deferred, evading capture and inscription.

\section{Conclusion: an archipelagraphic text}

My archipelagraphic analysis of The Fear of Losing Eurydice operates on a structural, thematic, and semantic level to trace connections between and among islands. It highlights the emancipatory potential of the archipelago of desire, which destabilizes Eurocentric stereotypes of islands and affects a poetic remapping of Caribbean. But the aim of this essay is not only to provide an example of archipelagraphy as a literary methodology. The textual strategies that The Fear of Losing Eurydice exhibits can also be used to provide a working definition of an archipelagraphic text. This extends beyond a book which is set on an archipelago. The 'double-destabilization' (Stratford et al., 2011, p. 114) that the archipelago represents - that deterritorializing of colonizing narratives, and their replacement with more emancipatory cartographies-must also be present within the text, not only in theme but also in structure and intent. Ghosh's The Hungry Tide can therefore be considered an archipelagraphic text, for it positions itself as a critique of the exoticising narrative often levelled at the Sundarbans, instead reviving its forgotten histories and stressing its liminality and multiplicity (Fletcher, 2011).

Whilst I do not think all archipelagraphic novels need necessarily exhibit such a high degree of experimentalism as The Fear of Losing Eurydice, I believe there should be some aspect of their structure or language that operates as a challenge to the linear narrative poetics found within the western Robinsonade. To Rebecca Weaver-Hightower (2007, p. ix), Robinsonades are "stories 
in which castaways could control the naturally bounded space of the island as they control the naturally bounded space of their bodies. The island-like book that colonial readers hold in their hands, then, contains a story of a body-like island." This evokes a geocentric model of enclosure, where the bounded island is inscribed and transformed by the castaway, and also enclosed by the circumscribed text. The Fear of Losing Eurydice stands in opposition to the Robinsonade, for it not only dissolves the boundaries of the island, remapping it as a signifier of multiplicity, but also 'opens out' the textual space of the novel through its staging of intertextuality as différance and through the endless cycles of meta-textual repetition indicated by the islario.

Both The Hungry Tide and The Fear of Losing Eurydice can also be considered archipelagraphic because of the way in which they explore the island from a variety of disciplinary and narrative perspectives, thereby replicating the multiplicity I have shown the archipelago embodies. I believe that a final quality of an archipelagraphic text is that it necessitates the reader as an active presence, tracing the Poetics of Relation between and among the islands within the text.

An archipelagraphic text can therefore be defined as a politically motivated text that deliberately effects a rewriting of island cartographies, one which divorces the signifier 'island' from the notions of boundedness and vulnerability. It does so by remapping insular and archipelagraphic cartographies, highlighting them as symbols of multiplicity, proliferating spaces that each reader interprets according to their desires. This re-reading facilitates the construction of multiple, inter-connected island stories.

\section{References}

Anckar, D. (2007). Archipelagos and political engineering: the impact of non-contiguity on devolution in small states. Island Studies Journal, 2(2), 193-208.

Baldachinno, G., \& Ferreira, E. (2013). Competing notions of diversity in archipelago tourism: transport logistics, official rhetoric and inter-island rivalry in the Azores. Island Studies Journal, 8(1), 84-104.

Barreto, R. (2004-5). Utopia deferred: the search for paradise in Julieta Campos's El miedo de perder a Eurídice. Caribe, 7(2), 37-51.

Benítez-Rojo, A. (1996). The repeating island: the Caribbean and the postmodern perspective. Durham: Duke University Press.

Brathwaite, E.K. (1999). Conversations, with Nathaniel Mackey. New York: We Press \& Xcp: Cross-Cultural Poetics.

Campos, J. (1993). The fear of losing Eurydice. L. Chambers (Trans.). Champaign: Dalkey Archive.

Campos, J. (1988). Fragmentos de un diario al margen de un libro. Un Heroísmo Secreto. México, D.F: Vuelta.

Campos, J. (1979). El miedo de perder a Eurídice. 1st ed. Mexico D.F: Joauquin Mortiz.

Cixous, H. (1976). The laugh of the Medusa. K. Cohen \& P. Cohen (Trans.). Signs, 1(4) 875893. https://doi.org/10.1086/493306

Compton, W. (2001). Bluesprint: black British Columbian literature and orature. Vancouver: Arsenal Pulp.

Constantakopoulou, C. (2007). The dance of the islands: insularity, networks, the Athenian

Empire, and the Aegean World. Oxford: Oxford University Press. https://doi.org/10.1093/acprof:oso/9780199215959.001.0001

DeLoughrey, E. (2007). Routes and roots: navigating Caribbean and Pacific island literatures. Honolulu: University of Hawai'i Press.

DeLoughrey, E. (2001). "The litany of islands, the rosary of Archipelagoes": Caribbean and Pacific archipelagraphy. ARIEL: A Review of International English Literature, 32, 22-51.

Derrida, J. (1982). Différance. The margins of philosophy. A. Bass (Trans.). Chicago: University of Chicago Press.

Eco, U. (1990). The open work. A. Cancogni (Trans.). Cambridge: Harvard University Press. 
Fallon, A.M. (2011). Global Crusoe: comparative literature, postcolonial theory and transnational aesthetics. Farnham: Ashgate.

Fallon, A.M. (2006). Julieta Campos and the repeating island. The Review of Contemporary Fiction, 26(2), 36-55.

Feracho, L. (2005). Linking the Americas: race, hybrid discourses, and the reformulation of feminine identity. New York: State University of New York Press.

Fletcher, L. (2011). Reading the postcolonial island in Amitav Ghosh's The Hungry Tide. Island Studies Journal, 6(1), 3-16.

Genette, G. (1997). Palimpsests: literature in the second degree. C. Newman \& C. Doubinsky (Trans.). Lincoln: University of Nebraska Press.

Ghosh, A. (2006). The hungry tide. Boston \& New York: Houghton Mifflin.

Glissant, É. (1997) Poetics of relation. B. Wing (Trans.). Ann Arbor: University of Michigan Press. https://doi.org/10.3998/mpub.10257

Glissant, É. (1989) Caribbean discourse: selected essays. M. Dash (Trans.). Charlottesville: Caraf.

Keep, C., McLaughlin, T., \& Parmar, R. (1993-2000). The new novel. The Electronic Labyrinth. http://www2.iath.virginia.edu/elab/hfl0260.html

Nyman, E. (2013). The island as container: islands, archipelagos, and player movement in video games. Island Studies Journal, 8(2), 269-284.

Philips, W. (1992). Africa and the Atlantic islands meet the Garden of Eden: Christopher Columbus's view of America. Journal of World History, 3(2), 149-164.

Portuondo, M. (2009). Secret science: Spanish cosmography and the New World. Chicago \& London: University of Chicago Press. https://doi.org/10.7208/chicago/9780226675374.001.0001

Pugh, J. (2013). Island movements: thinking with the archipelago. Island Studies Journal, 8(1), 9-24.

Ramos de Hoyos, M. (2016). El viaje a la isla: representaciones de la isla y la insularidad en tres novelas de Julieta Campos. México, D.F.: El Colegio de México.

Rodaway, P. (1994). Sensuous geographies: body, sense and place. London: Routledge. https://doi.org/10.4324/9780203306864

Stratford, E., Baldacchino, G., McMahon, E., Farbotko, C., \& Harwood, A. (2011). Envisioning the archipelago. Island Studies Journal, 6(2), 113-130.

Stratford, E. (2013). The idea of the archipelago: contemplating island relations. Island Studies Journal, 8(1), 3-8.

Tompkins, C. (2006). Latin American postmodernisms: women writers and experimentation. Gainesville: University Press of Florida.

Tompkins, C. (1996). Intertextuality as différance in Julieta Campos El Miedo de Perder a Eurídice: a symptomatic case of Latin American postmodernism. C. Ferman (Ed.). The postmodern in Latin and Latina American cultural narratives: collected essays and interviews (pp. 153-180). New York: Garland.

Torres Fiero, D. (2006). Julieta Campos by Danubio Torres Fiero. BOMB Magazine, 94. http://bombmagazine.org/article/2795/julieta-camposn

Weaver-Hightower, R. (2007) Empire islands: castaways, cannibals, and fantasies of conquest. Minnesota: University of Minnesota Press.

Worton, M., \& Still, J (1990) Intertextuality: theories and practices. Manchester \& New York: Manchester University Press. 